\title{
Imposex in Olivancillaria vesica vesica (Gmelin) (Gastropoda, Olividae) from a Southeastern Brazilian sandy beach
}

\author{
Carlos Henrique Soares Caetano ${ }^{1}$ \\ Ricardo Silva Absalão ${ }^{2}$
}

\begin{abstract}
Imposex, the development of male sex organs on the female, is registered and described for Olivancillaria vesica vesica (Gmelin, 1791) at Restinga da Marambaia beach, Rio de Janeiro state, Brazil.

KEY WORDS. Gastropoda, Olividae, Olivancillaria vesica vesica, imposex, sandy beaches, Rio de Janeiro, Brazil
\end{abstract}

Imposex, also known as pseudohermaphroditism, is characterized by the development of additional male sex organs (penis and/or vas deferens) on females (GIBBS \& BRYAN 1987). This is a widespread phenomenon within marine meso and neogastropds, known to occur in more than 150 species belonging to more than 60 genera world wide (FIORONI et al. 1991; OEHLMANN et al. 1996; MATTHIESSEN \& GIBBS 1998). Imposex has been recorded for South America, in Chile by GoODING et al. (1999), in Brazil by CASTRO et al. (2000) and in Argentina by PENCHASZADEH et al. (2001). This syndrome was intensively correlated with boating activity, and organotin compounds, mainly tributyltin (TBT), identified as the toxin responsible. Recent studies have reported that other compounds, such as phenyltin and ethanol, may also cause imposex (HoRIGUCHI et al. 1995; DAVIES et al. 1997).

In the family Olividae, imposex was previously recorded in two species, Olivella biplicata (Sowerby, 1825) (JENNER 1979) and Amalda australis (Sowerby, 1830) (STEWART et al. 1992). This study presents a brief characterization of imposex in the olivid Olivancillaria vesica vesica (Gmelin, 1791), from Restinga da Marambaia beach ( $23^{\circ} 03^{\prime}$ S; $43^{\circ} 34^{\prime}$ W), Rio de Janeiro State, Brazil. This is an open ocean beach, characterized by fine sands, gentle slope and intermediate morphodynamic type (SHORT \& WRIGHT 1983).

Specimens were collected in the intertidal zone during the months of May, June and November 1999 and June to August 2000. In the laboratory, shell length was measured with calipers, posteriorly cracked and open in a vice, and the animals removed and examined for sex determination. Individuals having capsule and albumen glands were identified as females. Females with male sex organs were identified as individuals exhibiting imposex.

1) Universidade do Rio de Janeiro. Avenida Pasteur 458, sala 411, Urca, 22290-240 Rio de Janeiro, Rio de Janeiro, Brasil. E-mail: chcaetano@zipmail.com.br

2) Departamento de Biologia Animal e Vegetal, Universidade do Estado do Rio de Janeiro. Avenida São Francisco Xavier 524, Maracanã, 20550-900 Rio de Janeiro, Rio de Janeiro, Brasil. E-mail: absalao@hotmail.com 
The penis length of males and imposexed females were measured with calipers $(0.1 \mathrm{~mm}$ accuracy). The relative penis length index (RPLI), relative penis size index (RPSI) and vas deferens sequence index (VDSI) were calculated (GIBBS et al. 1987), where: Relative Penis Length Index $(\%)=[($ mean penis length in females $) /($ mean penis length in males $)]^{*} 100$. Relative Penis Size Index $(\%)=[($ mean penis length in females $\left.)^{3} /(\text { mean penis length in males })^{3}\right]^{*} 100$. Because of logistical problems, the VDSI were calculated only for June and November 1999.

A total of 263 individuals were collected, of which 151 were males and 112 females. The occurrence of imposex was $100 \%$ for almost all months. The only exception was August 2000, where 2 out 41 females did not show a penis or a vas deferens.

The penis length of females exhibiting imposex ranged from 0.5 to $7.1 \mathrm{~mm}$ while males penis length ranged from 6.4 to $26.0 \mathrm{~mm}$ (Figs 1 and 2). Significant differences were observed between penis length of males and females (Mann-Whitney test $\mathrm{U}=16827.5, \mathrm{p}<0.0001$ ).

Mean penis lengths for males and females, mean shell length for both sexes, RPLI and RPSI values are show in table I. The values of RPLI and RPSI were low and varied from 15.64 to 37.95 and from 0.38 to 5.46 , respectively. The VDSI values were IV for June 1999 and varied from III to IV for November 1999. Vas deferens were already well-developed in all females observed.

Table I. Mean penis length, mean shell length, percentage of Imposex, RPLI and RPSI values for Olivancillaria vesica vesica.

\begin{tabular}{|c|c|c|c|c|c|c|c|c|c|}
\hline \multirow{2}{*}{ Period } & \multirow{2}{*}{$n$} & \multirow{2}{*}{ Male/female } & \multicolumn{2}{|c|}{ Mean penis length $(\mathrm{mm})$} & \multicolumn{2}{|c|}{ Mean shell length $(\mathrm{mm})$} & \multirow{2}{*}{$\begin{array}{l}\text { Imposex } \\
(\%)\end{array}$} & \multirow{2}{*}{$\begin{array}{l}\text { RPLI } \\
(\%)\end{array}$} & \multirow{2}{*}{$\begin{array}{c}\text { RPSI } \\
(\%)\end{array}$} \\
\hline & & & Males & Females & Males & Females & & & \\
\hline May 1999 & 34 & $19 / 15$ & $2.66 \pm 1.63$ & $11.05 \pm 1.81$ & $43.15 \pm 3.87$ & $37.16 \pm 4.25$ & 100 & 24.07 & 1.39 \\
\hline June 1999 & 32 & $25 / 07$ & $4.53 \pm 1.53$ & $13.75 \pm 3.48$ & $42.43 \pm 6.45$ & $38.06 \pm 6.14$ & 100 & 32.94 & 3.57 \\
\hline November 1999 & 35 & $19 / 16$ & $3.23 \pm 1.62$ & $8.51 \pm 1.26$ & $37.58 \pm 6.08$ & $38.09 \pm 4.75$ & 100 & 37.95 & 5.46 \\
\hline June 2000 & 34 & $20 / 14$ & $2.86 \pm 1.46$ & $12.55 \pm 1.90$ & $39.57 \pm 3.06$ & $40.25 \pm 5.09$ & 100 & 22.78 & 1.18 \\
\hline July 2000 & 30 & $11 / 19$ & $3.37 \pm 1.34$ & $16.90 \pm 2.30$ & $35.21 \pm 5.69$ & $35.72 \pm 7.53$ & 100 & 19.94 & 0.79 \\
\hline August 2000 & 100 & $59 / 41$ & $2.22 \pm 1.07$ & $14.19 \pm 2.07$ & $39.44 \pm 4.25$ & $39.53 \pm 5.14$ & 95 & 15.64 & 0.38 \\
\hline
\end{tabular}

In the 1950's a anatomical study was carried out in the coast of São Paulo State, Southeastern Brazil with the same species and no signs of female masculinization were observed (MARCUS \& MARCUS 1954) but TBT-based antifoulants first came on the market only in the 1960's and become widely used on the hulls of ships in the mid-1970's (WAITE et al. 1991).

Imposex occurs possibly as a result of TBT pollution although other causes have not been ruled out. Restinga da Marambaia beach itself does not seem to have a conspicuous source of organotin pollution, but offshore vessels traffic is relatively intense and the effect of water currents coming from heavily polluted areas nearly, such as Sepetiba Bay, should not be discarded. Thus, future studies should include laboratory experiments to confirm the relationship of cause-effect between imposex development in $O$. vesica vesica and TBT or other organotin compounds. 


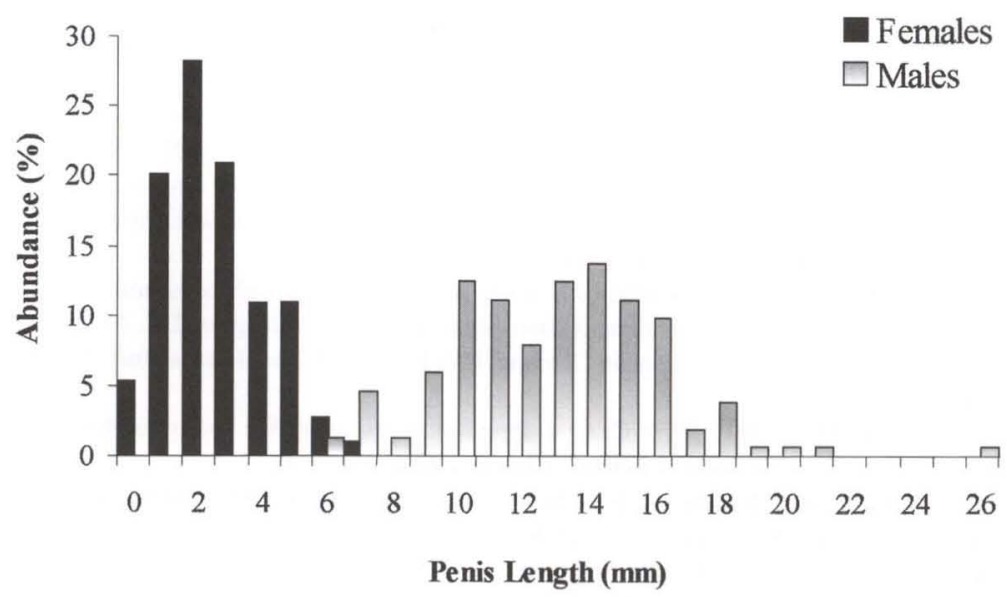

Fig. 1. Penis length $(\mathrm{mm})$ distribution for males and females of Olivancillaria vesica vesica.

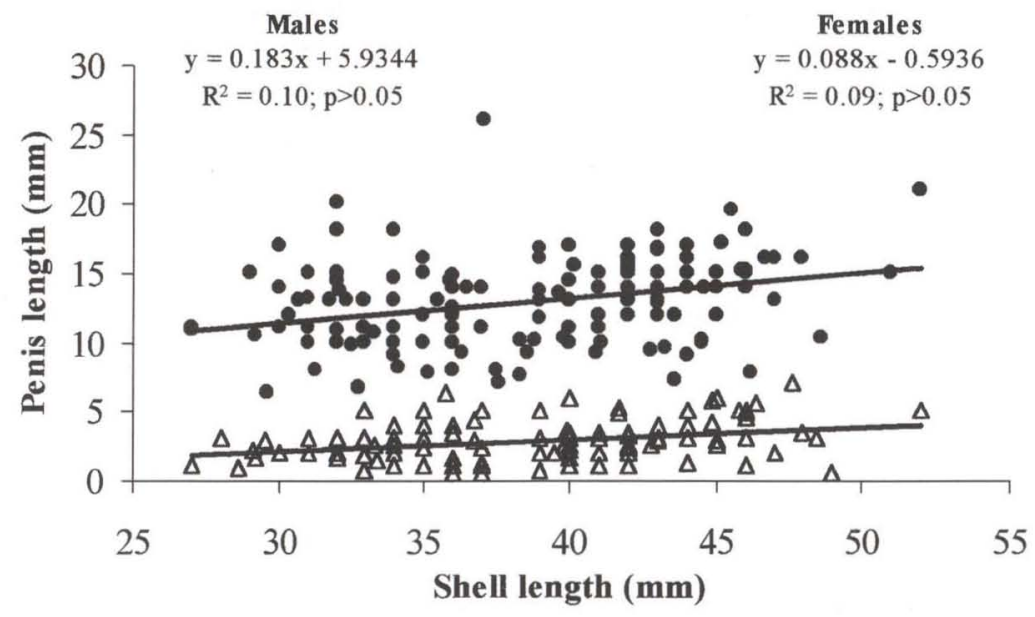

Fig. 2. Linear relationship between shell $(\mathrm{mm})$ and penis length $(\mathrm{mm})$ for males $(\bullet)$ and females $(\triangle)$.

\section{REFERENCES}

Castro, I.B.; H. Matthews-Cascon \& M.A. Fernandez. 2000. Imposex em Thais haemastoma (Linnaeus, 1767) (Mollusca: Gastropoda), uma indicação da contaminação por organoestânicos na costa do município de Fortaleza, Ceará, Brasil. Arq. Ciên. Mar., Fortaleza, 33: 51-56.

Davies, I.M.; M.J.C. HaRding; S.K. Bailey; A.M. ShankS \& R. LANGe. 1997. Sublethal effects of tributyltin oxide on the dogwhelk Nucella lapillus. Mar. Ecol. Progr. Ser. 158: 191-204.

Fioroni, P.; J. Oehlmann \& E. Stroben. 1991. The pseudohermaphroditism of prosobranchs; morphological aspects. Zool. Anz. 226: 1-26.

Gibis, P.E. \& G.W. Bryan. 1987. TBT paints and the demise of the dog-whelk, Nucella lapillus (Gastropoda). Proc. Oceans'87, New York, 4: 1482-1487. 
GibBs, P.E.; G.W. Bryan; P.L. PAscoe \& G.R. BurT. 1987. The use of dogwhelk (Nucella lapillus) as an indicator of TBT contamination. Jour. Mar. Biol. Ass. UK 67: 502-524.

Gooding, M.; C. Gallardo \& G. Leblanc. 1999. Imposex in three marine gastropod species in Chile and potential impact on muriciculture. Mar. Pollut. Bull., Oxford, 38 (12): 1227-1231.

Horiguchi, T.; H. Shiraishi; M. Shimizu; S. Yamazaki \& M. Morita. 1995. Imposex in Japanese gastropods (Neogastropoda and Mesogastropoda): effects of tributyltin and triphenyltin from anti-fouling paints. Mar. Pollut. Bull., Oxford, 31: 402-405.

Jenner, M.G. 1979. Pseudohermaphroditism: a newly recognized sexual phenomenon in Ilyanassa obsoleta and other Neogastropoda. Dissertation Abstr. Int. (B), Washington, DC, 40: 1-17.

Marcus, E. \& E. Marcus. 1954. Studies on Olividae. Bol. Fac. Fil. Cienc. Letras Univ. São Paulo, Zoologia, 22: 99-188.

Matthiessen, R. \& P.E. Gibbs. 1998. Critical appraisal of the evidence for tributyltin-1nediated endocrine disruption in mollusks. Environ. Toxicul. Chein. 17: 37-43.

Oehlmann, J.; P. Fioroni; E. Stroben \& B. Markirt. 1996. Tributyltin (TBT) effects on Ocinebrina aciculata (Gastropoda: Musicidae): Irrposex develupment, sterilization, sex change and populatior: decline. Sci. Total Environ. 188: 205-223.

Penchaszadeh, P'.F.; A. Averbus \& M. Ćledón. 2001. Inposex in gastropods from Argentina (South-Western Atlantic). Mar. Pollut. Bull., Oxford, 42 (9): 790-791.

SHORT, A.D. \& L.D. WRIGHT. 1983. Physical variability if sandy beiches, p. 133-144. In: A. MCLACHLAi $\&$ T. Erasmus (Eds). Sandy beaches as ecosystens. W. Junk, The Hague, IV+757p.

Stewart, C.; S.J. Mora; M.R. Jones \& M.C. Miller. i 992. Imposex in New Zealand neogastropods. Mar. Pollut. Bull., Oxford, 24 (4): 204-209.

Waite, M.E.; M.J. Waldock; J.E. Thain; D.J. Smith \& S.J. Milton. 1991. Reductions in TB'T concentrations in UK estuaries following legislation in 1986 an:1 1987. Mar. Environ. Res., Oxford, 32: 89-111.

Received in 18.VII.2002; accepted in 23.XI.2002. 